学術論文

\title{
自動バランスプラットフォームを有する 自律移動ロボットの開発
}

\section{Development of an Autonomous Mobile Robot with Balance Platform}

\author{
佐々木 実"1 (正員)，ハン カヒョウ*1，松下 光次郎 ${ }^{* 1}$ (正員)
}

Minoru SASAKI (Mem.), Jiabing PAN, Kojiro MATSUSHITA (Mem.)

\begin{abstract}
This research presents development of an Autonomous Mobile Robot with Leveled Platform. Autonomous Mobile system based on information fusion obtained from camera and laser scanner. leveling of the platform was controlled by servo motor based on the posture data from 6 axis sensor filtered by Madgwick filter. Finally, the robot could move autonomously in complicated environments and could keep the platform leveled.
\end{abstract}

Keywords: autonomous mobile robot, balance platform, Madgwick filter, SLAM.

(2020 年 5 月 20 日受付, 2021 年 3 月 15 日再受付)

\section{1 緒言}

近年の産業界の労働力不足の解決策として, 軽作業 の自動化が注目されており, 無人搬送車（自律移動口 ボット）の研究開発が進んでいる。従来研究において は, ライントレーサー, ランドマークナビゲーション, 測域センサによる自己位置推定など自律移動性能の向 上を主眼に置いており，無人搬送車への実用化も進ん でいる。それに対し自律移動制御以外の機能である運 搬対象である物体の安定化に関する研究は少ないと言 える。すなわち，無人搬送車の普及のためには，単な る整地走行だけではなく, 屋外農場のような不整地に よる利用も想定すべきであるため, 従来の自律移動制 御でナビゲーションは達成できたとしても, 運搬対象 への過度な傾きや振動が加わったとすると, 無人搬送 の目的を達成していないことになる。

そこで本研究では，プラットフォーム（荷台）に 6 軸モーションセンサ（加速度 3 軸, ジャイロ 3 軸）と モータを搭載し, 不整地の状態に応じたプラットフォ 一ム姿勢制御系を有する自律移動ロボットを提案する。 なお, ナビゲーションとしては, カメラによるランド マークナビゲーションと測域センサによる障害物検知 を組み合せた人追従機能を実装し，その上で，実際の 不整地（芝生, 砂利道) における提案システムの有効

連絡先：佐々木 実, テ501-1193 岐阜県岐阜市柳戸 1-1, 岐阜大学工学部機械工学科,

e-mail: sasaki@gifu-u.ac.jp

${ }^{* 1}$ 岐阜大学
性の検証を行った。

\section{2 提案システム}

ハードウェア構成は, 駆動車輪用サーボモータ Dynamixel XH540（2 個), 補助輪（2 個）, バランスプ ラットフォーム用モータ (2 個), 6 軸モーションセン サ (1 個)，センサフュージョンプロセス用マイコン (1 個), USB カメラ (1 個), 測域センサ RPLidar S1（1 個)，アルミフレーム, Linux 搭載ノート PC である。駆 動機構は, Dynamixel モー夕駆動 2 輪と補助 2 輪で構 成される同軸二輪であり, 超信地旋回を可能としてい る。自律移動制御としては, Linux 搭載 PC の Robot Operation System（ROS）を基盤にカメラ画像分析と測 域センサの点群分析を統合し，色ターゲットの方向検 出と距離検出を組み合わせ，人の背中の黄色テープを ターゲットとした人追従制御を実現している。自動バ ランス・プラットフォームは, 内蔵の 6 軸モーション センサから得られる加速度值・角速度值に対してセン サフュージョンアルゴリズム(Madgwick Filter)を適用 し, 姿勢 (Roll 角度・Pitch 角度) を算出, バランス維

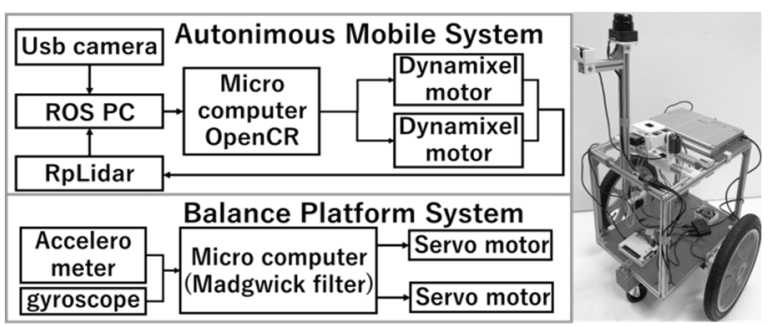

Fig. 1 Proposed robot system. 
持のためのモータ角度制御を行う。

\section{1 自律移動システム}

本研究で提案する自律移動システムは機体方向を 制御する画像分析技術による目標識別左右方向調整シ ステムと目標距離を保持する距離接近調整システム二 つの部分で構成されている。全体システム構成は Fig. 2 に示されている。左右調整システムはカメラから目 標特定色識別後, 機体方向調整する。機体方向調整し た後測域センサから目標との距離を計算し指定距離ま で接近する。その上で，識別できないもしくは目標口 ストする場合は自動停止とする。

2.2 カメラ画像分析 : 色識別に基つく機体左右調整シ ステム

目標識別システムは特定色検出画像分析技術で実 現している。カメラ画像から目標を識別するまでの指 定色識別，抽出及び重心計算・検出画像分析アルゴリ ズムを Fig. 3 に示す。カメラから取得した画像をカメ ラ画像フォーマットRGB (赤, 緑, 青) 色空間から画 像処理用フォーマット HSV (色相, 彩相, 輝度) 色空 間へ変換, 変換した画像を設定された閾值で二值化処 理する。処理した黒白画像を白部分だけ抽出して重心 を計算し，目標点として表示される。

左右方向調整システムを Fig. 3 に示す。カメラから 得られた画像の指定色を抽出し目標と識別しながら口 ボットの中心位置を目標位置まで調整する。

\section{3 目標接近距離保持システム}

Fig. 4 に示されるように目標捕捉システムから目標

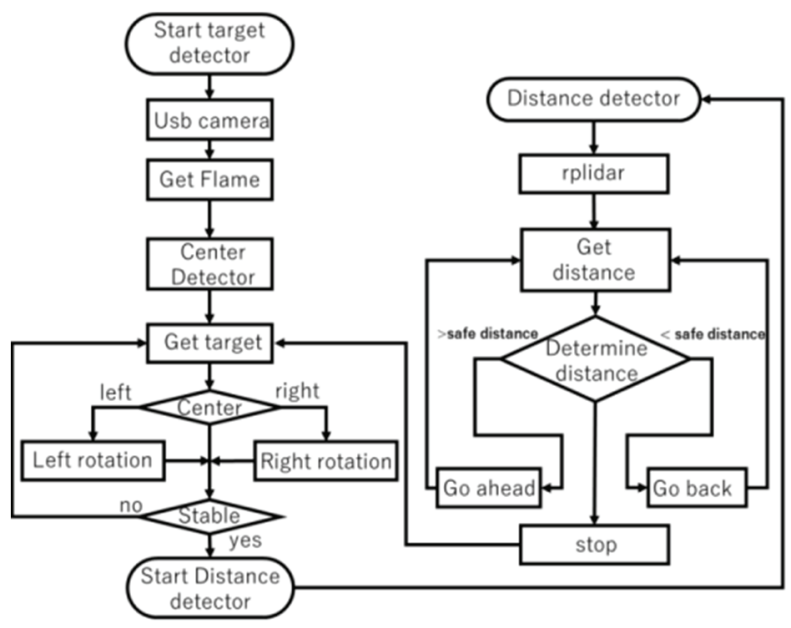

Fig. 2 Proposed robot flowchart.

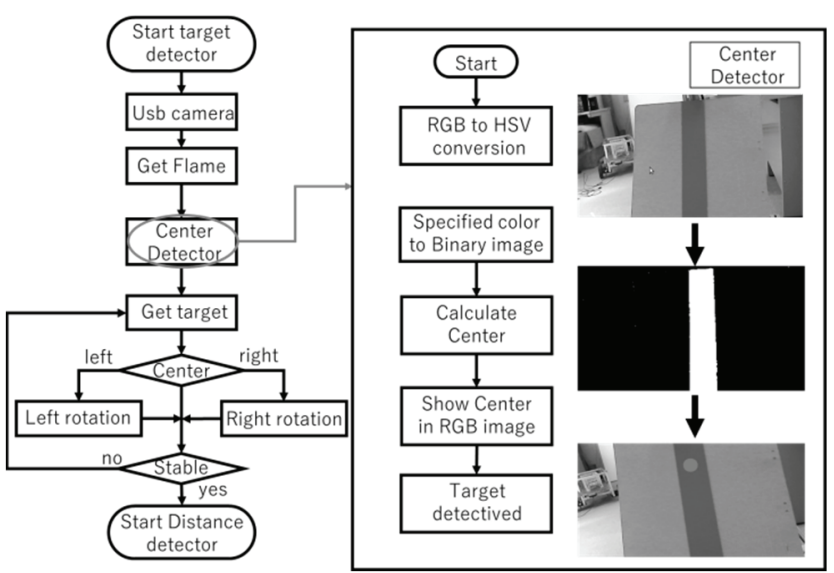

Fig. 3 Target recognition algorithm.

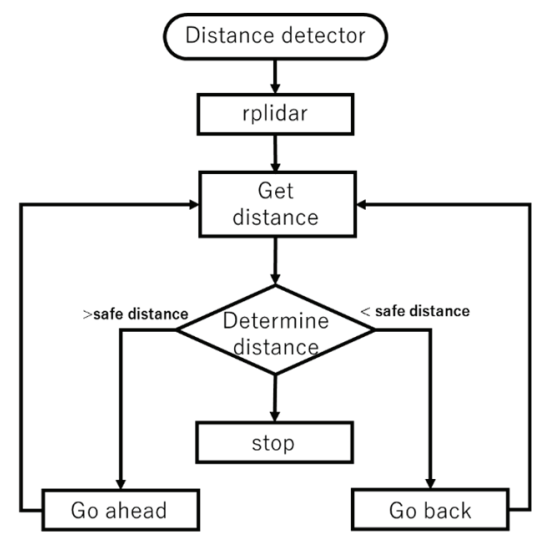

Fig. 4 Target follow algorithm.

を確認，捕捉し，ロボットの方向を調整した後，測域 センサから目標との距離を算出し, 事前に設定された 距離まで接近する。なお，もし前進途中に目標が失わ れた場合には，目標ロストの原因で距離計測プログラ ムが起動できないので，ロボットは停止する。

$$
2.4 \text { プラットフォーム自動バランスシステム }
$$

本研究では，走行中機体の姿勢変化が影響されず, プラットフォームの水平位置を保持する姿勢制御器を 導入している。故にプラットフォームの姿勢を制御す る前に機体の安定な姿勢情報が必要である。安定な姿 勢計測を行う為には，現在の姿勢を計測し，修正する システムを構築する必要がある。姿勢の計測にはモー ションセンサを用いる方法が一般的であるが，6 軸モ ーションセンサから計測したデータにはいくつかの問 題がある。

加速度センサは物体に作用するすべての直線的な 力を $[\mathrm{mV} / \mathrm{g}]$ の単位で測定する。動いている物体は，常 に作用する静的な力としての重力と合わせて，加速度 
のような動的な運動を示すことがある。物体に加速度 センサを取り付けることにより, 物体に働く加速度と 引力を測定できる。しかし, 加速度センサは時間が経 つと位置誤差を示寸傾向がある。一方, ジャイロスコ ープは, 物体に働く角速度の時間変化率 $[\mathrm{mv} / \mathrm{deg} / \mathrm{sec}]$ の 単位で示す。物体にジャイロスコープを取り付けるこ とにより, センサは物体の角度変化をスムーズに測定 するが，加速度センサと同じように，ジャイロスコー プでも時間とともに徐々に角度誤差が増加する[1]。

加速度センサとジャイロセンサは，それぞれの特性 によって，互いに補正することができる。補正方法と して Madgwick Filter[2]を用いる。 Madgwick Filter は S.O.H. Madgwickにより提唱されたもので,アルゴリズ ムをクォータニオン (4 元数) ベースにすることで, 補正精度の高いカルマンフィルタと同等の精度ながら, 処理時間を大幅に短縮している。クォータニオンはベ クトル $\left(\boldsymbol{q}_{1}\right)$ とスカラー $\left(\boldsymbol{q}_{2}, \boldsymbol{q}_{3}, \boldsymbol{q}_{4}\right)$ の 4 成分で 3 次元空 間の回転を表現する。このときフレームA に対するフ レーム B の向きは,

$$
\begin{aligned}
& { }_{B}^{A} \widehat{q}=\left[\boldsymbol{q}_{1}, \boldsymbol{q}_{2}, \boldsymbol{q}_{3}, \boldsymbol{q}_{4}\right] \\
& =\left[\cos \frac{\theta}{2},-\boldsymbol{r}_{x} \sin \frac{\theta}{2},-r_{y} \sin \frac{\theta}{2},-r_{z} \sin \frac{\theta}{2}\right]
\end{aligned}
$$

とし，またベクトル部の符号を反転した共役クォータ ニオンを

$$
{ }_{B}^{A} \widehat{\boldsymbol{q}}^{*}={ }_{A}^{B} \widehat{\boldsymbol{q}}=\left[\boldsymbol{q}_{1},-\boldsymbol{q}_{2},-\boldsymbol{q}_{3},-\boldsymbol{q}_{4}\right]
$$

と表す。フレーム $\mathrm{A}$ からフレーム $\mathrm{C}$ への向きは,

$$
{ }_{C}^{A} \widehat{\boldsymbol{q}}={ }_{C}^{B} \widehat{\boldsymbol{q}} \otimes{ }_{B}^{A} \widehat{\boldsymbol{q}}
$$

と表される。これがクォータニオンの基本表現となる。

続いて, Madgwick filter におけるクォータニオンの 推定アルゴリズムを示す。始めにセンサフレームの角 速度はクォータニオンを用いて,

$$
{ }^{s} \omega=\left[0, \omega_{x}, \omega_{y}, \omega_{z}\right][\mathrm{rad} / \mathrm{s}]
$$

と表される。また, アースフレームからセンサフレ 一ムへのクォータニオンによる回転の時間微分は以下 のようになる。

$$
{ }_{E}^{S} \dot{\boldsymbol{q}}=\frac{1}{2}{ }_{E}^{S} \widehat{\boldsymbol{q}} \otimes{ }^{S} \omega
$$

これは，離散時間では時刻 $\mathrm{t}$ における姿勢のクォー タニオンを ${ }_{E}^{S} \dot{\boldsymbol{q}}_{\omega, t}$, 時刻 $\mathrm{t}-1$ における姿勢の推定值を ${ }_{E}^{S} \widehat{\boldsymbol{q}}_{\boldsymbol{e s t}, \boldsymbol{t}-\mathbf{1}}$ とすると,

$$
\left\{\begin{array}{l}
{ }_{E}^{S} \dot{\boldsymbol{q}}_{\omega, t}=\frac{1}{2}{ }_{E} \widehat{\boldsymbol{q}}_{e s t, t-1} \otimes{ }^{s} \omega_{t} \\
{ }_{E}^{S} \boldsymbol{q}_{\omega, t}=\frac{1}{2}{ }_{E} \widehat{\boldsymbol{q}}_{\omega, t}+{ }_{E} \dot{\boldsymbol{q}}_{\omega, t} \Delta t
\end{array}\right.
$$

となる。

加速度センサの值は本来重力加速度と運動により 発生する加速度を合わせたものとなるが，ここでは重 力加速度のみを考える。この時, アースフレームでそ の真值が分かっているとすれば，センサフレームで計 測される值をクオータニオンから推測でき， 2 つのべ クトルの差を求められる。その差分が最も小さくなる 姿勢クオータニオン ${ }_{E}^{S} \widehat{\boldsymbol{q}}$ が最も適切な姿勢だと考えら れる。

$$
\min \left({ }_{E}^{S} \widehat{\boldsymbol{q}} \in \boldsymbol{R}^{4}\right) \boldsymbol{f}\left({ }_{E}^{S} \widehat{\boldsymbol{q}},{ }^{E} \widehat{\boldsymbol{d}},{ }^{S_{\widehat{s}}}\right)
$$

$f\left({ }_{E}^{S} \widehat{\boldsymbol{q}},{ }^{E} \widehat{d},{ }^{S} \widehat{s}\right)={ }_{E}^{S} \widehat{\boldsymbol{q}}^{*} \otimes{ }^{E} \widehat{d} \otimes{ }_{E}^{S} \widehat{\boldsymbol{q}}-{ }^{S} \widehat{s}$

$$
\begin{gathered}
{ }_{E}^{S} \widehat{\boldsymbol{q}}=\left[\boldsymbol{q}_{1}, \boldsymbol{q}_{2}, \boldsymbol{q}_{3}, \boldsymbol{q}_{4}\right] \\
{ }^{E} \widehat{\boldsymbol{d}}=\left[\mathbf{0}, \boldsymbol{d}_{x}, \boldsymbol{d}_{y}, \boldsymbol{d}_{z}\right] \\
S_{\widehat{s}}=\left[\mathbf{0}, \boldsymbol{s}_{x}, \boldsymbol{s}_{y}, \boldsymbol{s}_{z}\right]
\end{gathered}
$$

このとき通常はヘッセ行列により最適值を求めるが, 計算負荷が増大寸るためここでは最急降下法を用いる。 このときのアルゴリズムは以下のようになる。

$$
{ }_{E}^{S} q_{k+1}={ }_{E}^{S} \hat{q}_{k}-
$$

$$
\nabla \boldsymbol{f}\left({ }_{E}^{S} \widehat{q},{ }^{E} \widehat{d},{ }^{S} \widehat{s}\right)=J^{T}\left({ }_{E}^{S} \widehat{q},{ }^{E} \widehat{d}\right) f\left({ }_{E}^{S} \widehat{q},{ }^{E} \widehat{d},{ }^{S} \widehat{s}\right)
$$

$\boldsymbol{f}\left({ }_{E}^{S} \widehat{\boldsymbol{q}},{ }^{E} \widehat{\boldsymbol{d}},{ }^{S} \widehat{\boldsymbol{s}}\right)=$

$$
\left[\begin{array}{r}
2 d_{x}\left(\frac{1}{2}-q_{3}^{2}-q_{4}^{2}\right)+2 d_{y}\left(q_{1} q_{4}+q_{2} q_{3}\right) \\
+2 d_{z}\left(q_{2} q_{4}-q_{1} q_{3}\right)-s_{x} \\
2 d_{x}\left(q_{2} q_{3}-q_{1} q_{4}\right)+2 d_{y}\left(\frac{1}{2}-q_{2}^{2}-q_{4}^{2}\right) \\
+2 d_{z}\left(q_{1} q_{2}+q_{3} q_{4}\right)-s_{y} \\
2 d_{x}\left(q_{1} q_{3}+q_{2} q_{4}\right)+2 d_{y}\left(q_{3} q_{4}-q_{1} q_{2}\right) \\
+2 d_{z}\left(\frac{1}{2}-q_{2}^{2}-q_{3}^{2}\right)-s_{z}
\end{array}\right]
$$

$$
\begin{aligned}
& J^{T}\left({ }_{E}^{S} \widehat{q},{ }^{E} \widehat{d}\right)= \\
& {\left[\begin{array}{cc}
2 d_{y} q_{4}-2 d_{z} q_{3} & 2 d_{y} q_{3}+2 d_{z} q_{4} \\
-2 d_{x} q_{4}+2 d_{z} q_{2} & 2 d_{x} q_{3}-2 d_{y} q_{2}+2 d_{z} q_{1} \\
2 d_{z} q_{3}+2 d_{y} q_{2} & 2 d_{x} q_{4}-2 d_{y} q_{1}+2 d_{z} q_{2}
\end{array}\right.}
\end{aligned}
$$




$$
\left.\begin{array}{c}
-4 d_{x} q_{3} 2 d_{y} q_{2}-2 d_{z} q_{1} \\
2 d_{x} q_{2}+2 d_{z} q_{4} \\
2 d_{x} q_{1}+2 d_{y} q_{4}-4 d_{z} q_{3} \\
-4 d_{x} q_{4}+2 d_{y} q_{1}+2 d_{z} q_{2} \\
-2 d_{x} q_{1}-4 d_{y} q_{4}+2 d_{z} q_{3} \\
2 d_{x} q_{2}+2 d_{y} q_{3}
\end{array}\right]
$$

次に加速度センサの計測值を運動と重力加速度に よるものとに分けて正規化し，

$$
\begin{gathered}
{ }^{E} \widehat{\boldsymbol{g}}=[0,0,0,1] \\
{ }^{E} \widehat{\boldsymbol{a}}=\left[0, a_{x}, a_{y}, a_{z}\right]
\end{gathered}
$$

とする。これを式(14),(15)に代入すると，以下が得ら れる。

$$
\begin{gathered}
f\left({ }_{E}^{S} \widehat{\boldsymbol{q}},{ }^{S} \widehat{\boldsymbol{a}}\right)=\left[\begin{array}{c}
2\left(q_{2} q_{4}-q_{1} q_{3}\right)-a_{x} \\
2\left(q_{1} q_{2}+q_{3} q_{4}\right)-a_{y} \\
2\left(\frac{1}{2}-q_{2}^{2}-q_{3}^{2}\right)-a_{z}
\end{array}\right] \\
\boldsymbol{f}\left({ }_{E}^{S} \widehat{q},{ }^{S} \widehat{a}\right) \\
=\left[\begin{array}{cccc}
2 q_{3} & 2 q_{4} & -2 q_{1} & 2 q_{2} \\
2 q_{2} & 2 q_{1} & 2 q_{4} & 2 q_{3} \\
0 & 2 q_{2} & -4 q_{3} & 0
\end{array}\right]
\end{gathered}
$$

よって，更新式は，

$$
{ }_{E}^{S} q_{\nabla, t}={ }_{E}^{S} \widehat{q}_{e s t, t-1}-\mu_{t} \frac{\nabla f}{|| \nabla f||}
$$

となる。

ここで, $\mu_{t}$ の最適值は不必要に大きなステップサイ ズに起因するオーバーシュートを回避するため ${ }_{E}^{S} \boldsymbol{q}_{\nabla, t}$ の収束率として定義できる。よって， $\mu_{t}$ は以下の式で 求められる。

$$
\mu_{t}=\alpha||_{E}^{S} \dot{q}_{\omega, t} \| \Delta \mathrm{t}, \quad \alpha>\mathbf{1}
$$

最後に上記の方法で加速度から計算した姿勢 $\left({ }_{E}^{S} q_{\nabla, t}\right)$ と 角速度から計算した姿勢 $\left({ }_{E}^{S} q_{\omega, t}\right)$ によるフィルタフュー ジョンのアルゴリズムを示す。

最終的な推定值を ${ }_{E}^{S} \boldsymbol{q}_{\mathrm{est}, t}$ とし, 各姿勢クォータニオ ンの重みを $\gamma_{t}$ として以下のように計算する。

$$
\begin{aligned}
{ }_{E}^{S} & q_{\mathrm{est}, t}=\gamma_{t E}^{S} q_{\nabla, t}+\left(1-\gamma_{t}\right)_{E}^{S} q_{\omega, t}, \\
& 0 \leq \gamma_{t} \leq \mathbf{1}
\end{aligned}
$$

ここで, $\gamma_{t}$ の最適值は $S_{E}^{S} q_{\omega, t}$ の重みの発散が ${ }_{E}^{S} q_{\nabla, t}$ の重み の収束に等しいことにより定義でき,

$$
\left(1-\gamma_{t}\right) \beta=\gamma_{t} \frac{\mu_{t}}{\Delta t}
$$

$$
\gamma_{t}=\frac{\beta}{\frac{\mu_{t}}{\Delta t}+\beta}
$$

と表される。ここで, $\frac{\mu_{t}}{\Delta t}{ }_{E}{ }_{E}^{S} q_{\nabla, t}$ の収束率であり, $\beta$ は ${ }_{E}^{S} q_{\omega, t}$ の発散率である。

また， $\boldsymbol{\alpha}$ が $\boldsymbol{\mu}_{\boldsymbol{t}}$ に対して非常に大きいと仮定すると， 式(20)は,

$$
{ }_{E}^{S} q_{\nabla, t} \approx-\mu_{t} \frac{\nabla f}{|| \nabla f||}
$$

と近似できる。同様に式(24)も

$$
\gamma_{t} \approx \frac{\beta \Delta t}{\mu_{t}}
$$

となり $\gamma_{t} \approx 0$ と近似できる。

ここで式(6)，(25)，(26)を式(22)に代入し，

$$
\begin{aligned}
& { }_{E}^{S} q_{\mathrm{est}, t}=\frac{\beta \Delta t}{\mu_{t}}\left(-\mu_{t} \frac{\nabla f}{|| \nabla f \mid}\right) \\
& +(\mathbf{1}-\mathbf{0})\left({ }_{E}^{S} \widehat{\boldsymbol{q}}_{\mathrm{est}, t-1}+{ }_{E}^{S} \dot{\boldsymbol{q}}_{\boldsymbol{\omega}, t} \Delta t\right)
\end{aligned}
$$

を得られる。この式は次式のように簡略化でき, フィ ルタ更新式が得られる。

$$
{ }_{E}^{S} q_{\mathrm{est}, t}={ }_{E}^{S} \widehat{\boldsymbol{q}}_{\mathrm{est}, t-1}+{ }_{E}^{S} \dot{q}_{\mathrm{est}, t} \Delta t
$$

このとき，

$$
\begin{gathered}
{ }_{E}^{S} \dot{\boldsymbol{q}}_{\mathrm{est}, t}={ }_{E}^{S} \dot{\boldsymbol{q}}_{\omega, t}-\boldsymbol{\beta} \dot{\overrightarrow{q_{\varepsilon, t}}} \\
\beta \dot{\overline{q_{\varepsilon, t}}}=\frac{\nabla f}{\| \nabla f \mid}
\end{gathered}
$$

である。Fig.5はこのアルゴリズムのブロック図である。

6 軸モーションセンサから機体姿勢を得られた後, 姿勢制御機はサーボモータ $2 つ の ~ 2$ 自由度系で機体姿 勢変化に対応し，プラットフォームが常に平行を保つ ようになっている。その効果を Fig. 6 に示す。

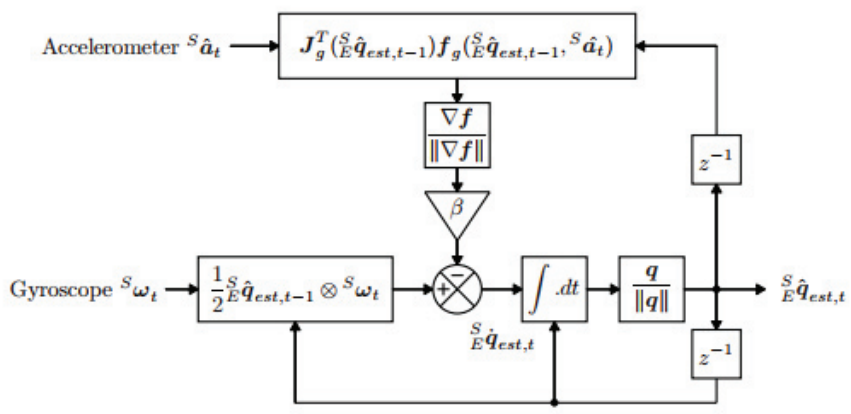

Fig. 5 Block diagram of Madgwick filter. 


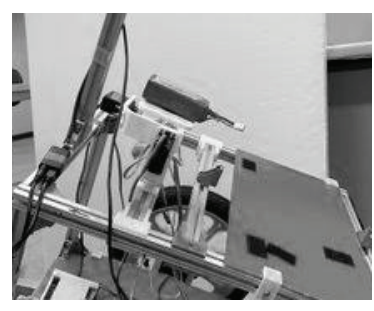

(a) Without control

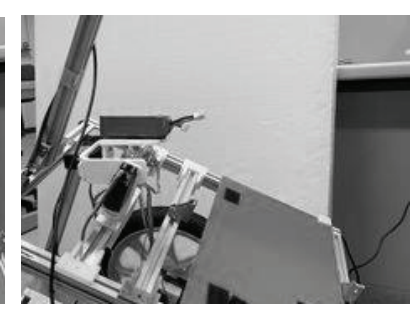

(b) With control
Fig. 6 Attitude control effect.

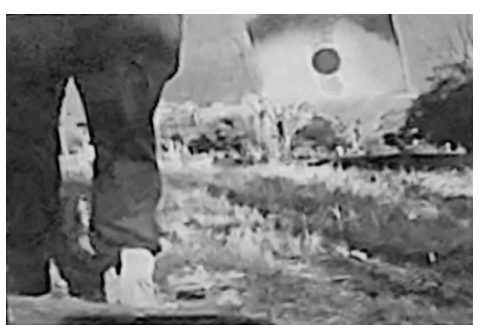

Fig. 7 Color detection.

\section{3 検証実験 $1:$ 自律追従システム検証実験}

\section{1 カメラ画像分析 : 色識別}

本項ではカメラから特定色識別機能の検証を行う。 識別率を保障するため, 今回は検出しやすい黄色を選 択する。実験方法はパネルの上で黄色テープを貼り付 けてカメラに向けて左右に振り回し, 太陽光の影響下 での識別機能の有効性を検証する。

実駼結果を Fig. 7 に示す。結果として，カメラは太 陽光や周囲環境色に影響されず，パネルの上に貼り付 けた黄色テープを識別し, カメラ画像でテープの重心 （黑い点）を示した。以上，検証実験によって屋外で 安定的に黄色識別が可能であることを確認した。

\section{2 測域センサによる距離計測}

廊下でロボット位置を固定し人はロボットに向け て接近，測域センサからロボットと人との距離計測を 行う。実験結果を Fig. 8 に示寸。画像の左は測域セン サが検出した人の点群データ, 上下の点群は廊下の壁, 四角い枠内は人の点群データ, 円の中心はロボットの 中心位置を示している。右は測域センサから得られた 距離データである。結果として測域センサで点群デー タより人とロボットの距離が計測可能であることを確 認した。

\section{3 自律追従システム検証実験}

本項は 3.1 色識別システム及び 3.2 測域センサ距離

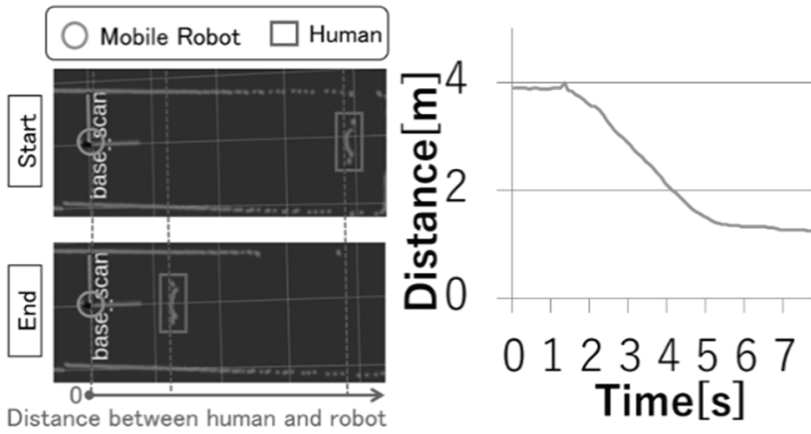

Fig. 8 Result of determined distance.

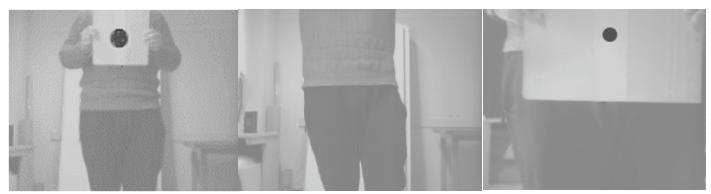

Fig. 9 Proposed robot system.

計測システムを統合し，色目標の方向検出機体方向調 整システムと距離検出自動接近距離保持システムを組 み合わせた自律追従システムの検証を行う。黄色テー プを目標として識別成功すると機体方向調整し追従, 目標を失う時に自動停止する。また，人との距離が一 定值以下になる場合, ロボットは自動で後退する機能 を検証する。

人の手で 3.1 の目標識別実験で目標と識別されたパ ネルを持ちロボットに搭載したカメラに向け, ロボッ トが目標を識別し，接近する途中パネルを一定時間隠 した後, 元の位置に戻す。設定された自動停止距離に 到達後, 人はパネルを持ってロボットに接近する。接 近する途中もパネルを一定時間隠した後, 元の位置に 戻す。ロボットの前進・後退・回転速度は $0.3[\mathrm{~m} / \mathrm{s}]$ とす る。設定自動停止距離は $1.5[\mathrm{~m}]$, 設定安全距離範囲は $0.9[\mathrm{~m}] \sim 1.5[\mathrm{~m}]$ とした。実験当時の画像を Fig. 9 に示す。

実験結果を Fig. 10 と Fig. 11 に示寸。線はロボット と人との距離, 灰色ブロックはロボットが停止してい る時間を示している。Fig. 10 に示すように設定された $1.5[\mathrm{~m}]$ の停止距離に到達したら, 停止することが確認 できた。また, 目標距離が $0.9[\mathrm{~m}]$ 以下になる時ロボッ トが自動で後退し, 設定された $0.9[\mathrm{~m}]$ の距離を保持す ることが確認できた。

\section{4 検証実験 2 : プラットフォーム性能検証実験}

屋外で典型的な地形や路面状況を選択し，プラット フォームを搭載したロボットを手動で走行させる。今 


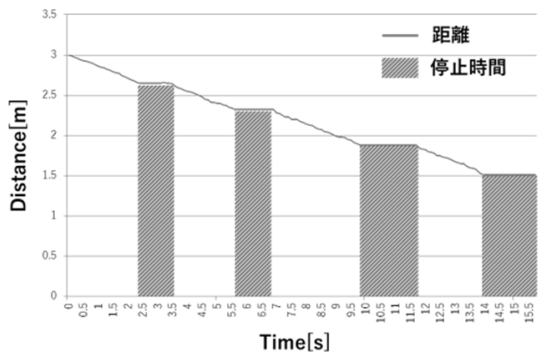

Fig. 10 Result of autonomous follow experiment.

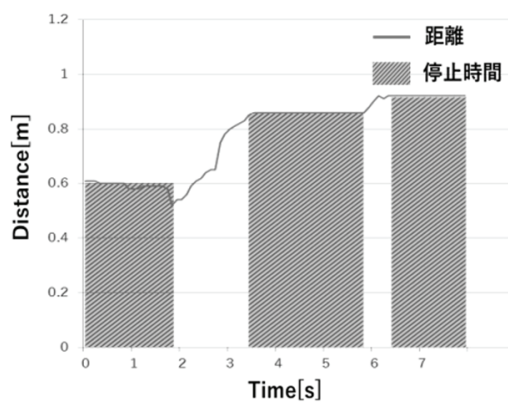

Fig. 11 Result of autonomous back up experiment.

回選択された地形と走行状態は以下のようになる。

i. 坂付きコンクリート地面坂走行

ii. 舗装路面走行

iii. 不整地走行 : 芝生

iv. 不整地走行 : 砂利道

それぞれの走行状態において機体の ROLL , PITCH 角度と自動バランス機能を起動した後のプラットフォ 一ムの Roll, Pitch 角度を比較する。走行速度は, $0.4[\mathrm{~m} / \mathrm{s}]$, 回転速度は $0.4[\mathrm{~m} / \mathrm{s}]$ 。コンクリート坂登り実験はロボ ットを坂の半ばに置いてロボットに坂を登らせ, また, 半ばに戻らせる。

不整地として芝生を対象とした 28 秒間の走行を行 い, プラットフォームの自動バランス機能の検証を試 タた。その結果, Fig. 12 と Fig. 13 に示されるように, 不整地の影響で機体の Pitch 角度が最大 $23[\mathrm{deg}]$ 変化す るのに対して，プラットフォームが 5 [deg]以内で収ま ること, また機体の Roll 角度が最大 $20[\mathrm{deg}]$ 変化する のに対して，プラットフォームが 7[deg]以内に収まる ことを確認した。また, 砂利道を対象とし, プラット フォームの自動バランス機能の検証を試みた。結果, 機体 Pitch 角度変化が最大 $13[\mathrm{deg}]$ 変化するのに対して, プラットフォームが 4[deg] 以内で収まること, 機体の Roll 角度が最大 $10[\mathrm{deg}]$ 変化するのに対して, プラット フォームが $4[\mathrm{deg}]$ 以内に収まることを確認した。

整地としてコンクリート路面環境で坂登り，坂下り 走行状態において走行した結果，機体のPitch 角度変

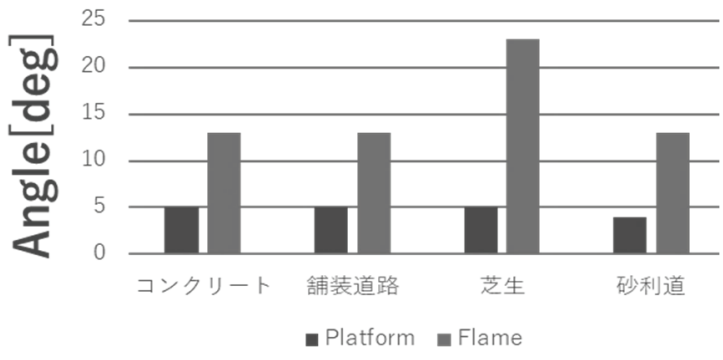

Fig. 12 Result with pitch angle.

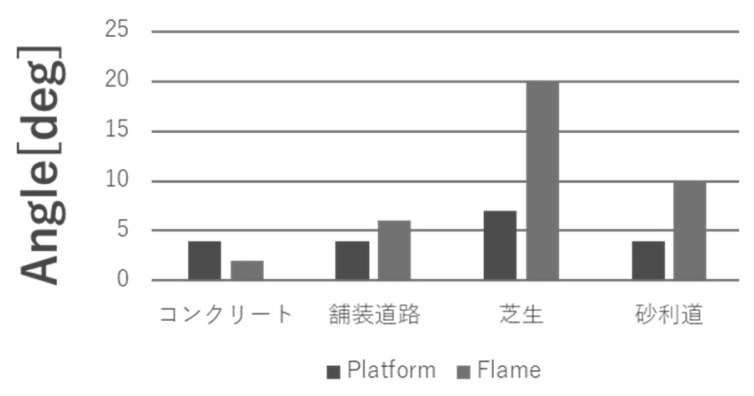

Fig. 13 Result with roll angle.

化が最大 $18[\mathrm{deg}]$ 変化するのに対して, プラットフォー ムが $5[\mathrm{deg}]$ 以内で収まること，また機体の Roll 角度は 2 [deg]変化するのに対して, プラットフォームが 1[deg] 以内に収まることを確認した。

舗装路面に対し，機体の Pitch 角度が最大 $13[\mathrm{deg}]$ 変 化するのに対して，プラットフォームが 4[deg]以内で 収まること，また機体の Roll 角度が最大 $6[\mathrm{deg}]$ 変化す るのに対して，プラットフォームが $4[\mathrm{deg}]$ 以内に収ま ることを確認した。

以上の実験結果により，今回提案する自動バランス (水平姿勢維持) システムは選定された屋外で典型的 な地形では有効であることが検証された。

\section{5 統合システム検証実験}

本実験では前章までで紹介・検証を行ってきたプラ ツトフォームの水平姿勢制御・色判別距離保持・自律 追従各機能を統合し，屋外環境で機能検証を行う。

今回はプラットフォームを搭載したロボットを実 際の屋外環境において, 人の背中に貼り付けた黄色テ ープを認識し，追従自律移動し，プラットフォームの バランス性能の最終検証実験を行う。

実験結果を Fig. 14, 実験当時の状況を Fig. 15 にそれ ぞれ示す。実験によりカメラは屋外環境において，太 陽光及びガラスの反射光に影響されず，正確に人の背 中に貼り付けた黄色テープを認識し, 人の後ろを追従 することが確認できた。また，プラットフォームは人 

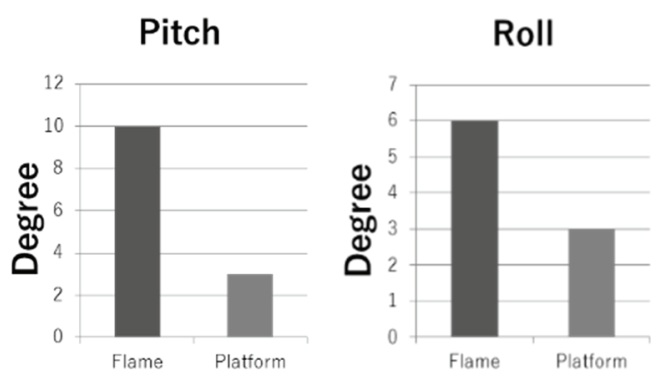

Fig. 14 Result with platform performance in comprehensive test.

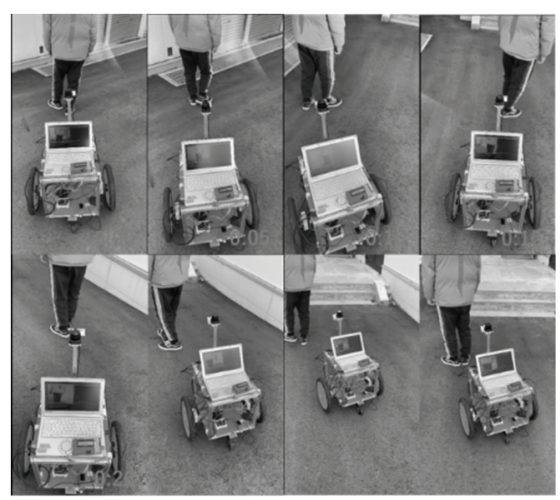

Fig. 15 Situation with comprehensive test.

\section{6 結言}

本研究は, 自動バランスを行う荷台プラットフォー ムを有する自律移動ロボットを目指し, 測域センサと カメラを組み合わせた自律移動機能と 6 軸モーション センサに基づくプラットフォーム自動水平姿勢維持機 能を構築した。その結果, ロボットが屋外不整地環境 移動時においても，プラットフォームは路面角度に影 響されず，水平を維持できることを確認し，提案シス テムの有効性を確認した。

\section{謝辞}

本研究の一部は, 内閣府からの地方大学・地域産業 創生交付金により支援を受けた。

\section{参考文献}

[1] Bonnie Bakerセンサ融合を加速度センサやジャイロスコ ープに適用

https:/www.digikey.jp/ja/articles/techzone/2018/jan/applysensor-fusion-to-accelerometers-and-gyroscopes

[2] Sebastian Madgwick, An efficient orientation filter for inertial and inertial/magnetic sensor arrays, Report $\mathrm{x}$-io and University of Bristol (UK), Volume 25, 2010.

[3] Morgan QUIGLEY, Brian Gerkey, William D. Smart, Programming Robots with ROS, O’REILLY, 2017. 